\begin{tabular}{|l|r|}
\hline \multicolumn{1}{|c|}{ Sciendo } & \\
\hline $\begin{array}{l}\text { (C) Article authors. This is an open access article distributed under } \\
\text { the Creative Commons Attribution-Non Commercial-No Derivs } \\
\text { licens. (http://creaticecommons.org/licenses/by.nc-nd/3.0/). }\end{array}$ & $\begin{array}{r}\text { ISSN online 2545-2819 } \\
\text { ISSN print } \quad \text { 0800-6377 }\end{array}$ \\
\hline DOI: $10.2478 /$ ncr-2021-0018 & $\begin{array}{r}\text { Received: Oct. 13, 2021 } \\
\end{array}$ \\
& Revision received: Dec. 8, 2021 \\
& Accepted: Dec. 9, 2021 \\
\hline
\end{tabular}

\title{
Evaluation of Rapid Repair of Concrete Pavements Using Precast Concrete Technology: A Sustainable and Cost-Effective Solution
}

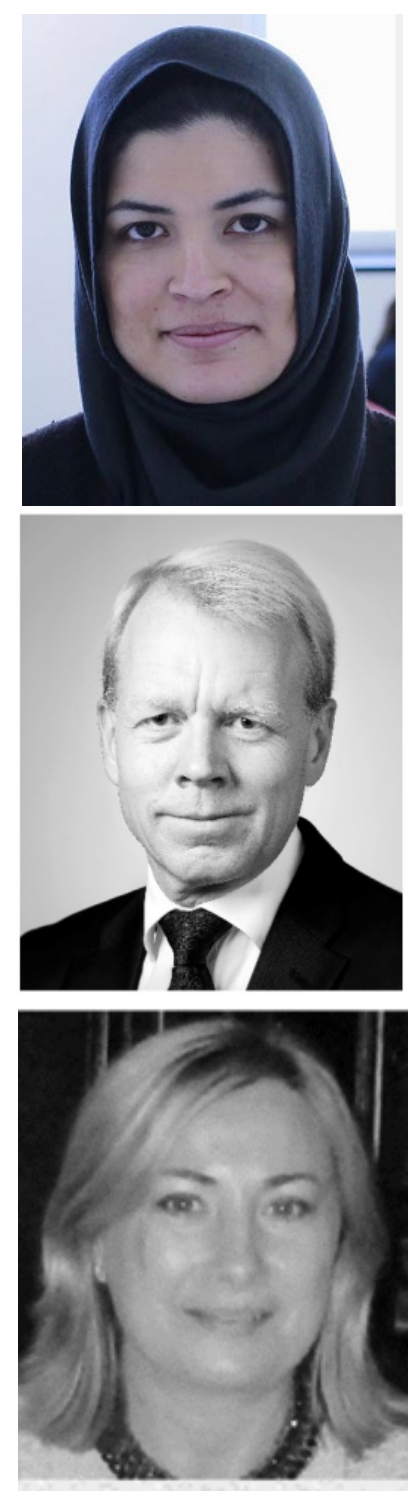

\author{
Saima Yaqoob \\ Ph.D. student, KTH Royal Institute of Technology \\ Dept. of Civil \& Architectural Engineering \\ Div. of Concrete Structures \\ Brinellvägen 23 \\ SE 10044 Stockholm, Sweden \\ saimay@kth.se
}

Johan Silfwerbrand

Professor, KTH Royal Institute of Technology

Dept. of Civil \& Architectural Engineering

Div. of Concrete Structures

Brinellvägen 23

SE 10044 Stockholm, Sweden

jsilfwer@kth.se

Larissa Strömberg

Ph.D. Affiliated faculty, KTH Royal Institute of

Technology

Dept. of Civil \& Architectural Engineering

Div. of Concrete Structures

Brinellvägen 23

SE 10044 Stockholm, Sweden

larissas@kth.se 


\begin{abstract}
Concrete and asphalt are the two competitive materials for a highway. In Sweden, the predominant material for the highway system is asphalt. But under certain conditions, concrete pavements are competitive alternatives. For example, concrete pavements are suitable for hightraffic volume roads, roads in tunnels, concentrated loads (e.g., bus stops and industrial pavement). Besides the load-carrying capacity, the concrete pavement has many advantages such as durability (wear resistance), resistance against frost heave, environment (pollution, recycling, and low rolling resistance leading to fuel savings), fire resistance, noise limitations, brightness, evenness and aesthetics.
\end{abstract}

Concrete pavements are long-lasting but need final repair. Single slabs may crack in the jointed concrete pavement due to various structural and non-structural factors. Repair and maintenance operations are, therefore, necessary to increase the service life of the structures. To avoid extended lane closures, prevent traffic congestions, and expedite the pavement construction process, precast concrete technology is a recent innovative construction method that can meet the requirement of rapid construction and rehabilitation of the pavement. This paper evaluates rapid repair techniques of concrete pavement using precast concrete technology by analysing three case studies on jointed precast concrete pavements. The study showed that the required amount of time to re-open the pavement to traffic is dramatically reduced with jointed precast concrete panels.

Key words: Jointed precast concrete panel, Concrete Pavements, Durability, Cracking, Repair, Maintenance.

1.

\title{
INTRODUCTION
}

\section{$1.1 \quad$ Background}

Pavements are engineered structures and constitute an essential part of our society. They are used as roads, runways, driveways, and parking lots and are expected to withstand the load applied from a vehicle such as an aircraft or a truck. The load-carrying capacity of a road depends not only on the pavement but also on the entire pavement system consisting of several layers. Good quality pavement is vital for the smooth working of any city.

Concrete and asphalt are competitive construction materials for busy roads, especially in and close to urban areas. There are several advantages and disadvantages of both materials. For example, the compressive strength and the stiffness of concrete are higher than asphalt. In contrast, asphalt is more flexible (providing a smooth and safe ride) and less sensitive to flexural stresses compared to concrete [1]. In Sweden, asphalt is the predominant highway material, only less than 1 percent of the total Swedish road network are concrete roads, see Table 1 [2]. The lower proportion of concrete road is due to several factors, e.g., lack of experience in the design and construction of concrete roads, high construction costs and strong asphalt industry, for details see $[1,2]$.

Concrete roads are the best alternatives under certain conditions that is valid for high volume traffic roads (close to urban areas), high demands on wear resistance, concentrated loads (e.g., bus stops \& industrial pavements), in tunnels with specific requirements on lifespan, durability, 
brightness and fire safety. Damages are rare on concrete pavements, but there is a need for rapid repair if it appears. There are also solutions to replace concrete pavement after service life, like applying asphalt pavement after pre-cracking/crushing of an old concrete pavement, but asphalt pavement is not a durable and economical solution for long-lasting pavements, especially for regions subjected to harsh climate conditions. A repair technology based on using precast concrete panels exists in the United States (U.S), but the technology has to be adapted to Swedish conditions.

Table 1: Concrete roads in Sweden [3].

\begin{tabular}{|c|c|c|c|}
\hline Section of road & Year & Length $(\mathrm{km})$ & Status \\
\hline E6 Vellinge & 1972 & 13 & Overlaid with asphalt \\
\hline E4 Helsingborg & 1978 & 7 & Overlaid with asphalt \\
\hline E4.65 Arlanda & 1990 & 1.6 & In use \\
\hline E6/120 Falkenberg 1 & 1993 & 15 & In use \\
\hline E6/120 Falkenberg 2 & 1996 & 13 & In use \\
\hline E20 Eskilstuna & 1999 & 14 & In use \\
\hline E4 Uppsala & 2006 & 23 & In use \\
\hline Total & & 87 & In use \\
\hline In use & & 67 & In use \\
\hline
\end{tabular}

Over the past 20 years, traffic volumes on the highway system have significantly increased, especially in urban areas leading in many instances to necessary rehabilitation and reconstruction of highway pavements earlier than expected. Pavement rehabilitation in urban areas is a challenge for highway agencies because of construction-related traffic congestion and safety problems. To avoid extended lane closures and prevent traffic congestions, many highway departments have started to investigate the method of rehabilitation and reconstruction that are faster and result in durable and long-lasting pavements. Precast concrete pavement systems (PCPS) have been shown the potential of promising and effective alternatives. Safety is also improved with the precast concrete pavement by reducing road users' and workers' exposure to construction traffic [4].

Previously, the use of rapid-setting concrete was a preferable option for short-closure windows [5]. A few years ago, six full-scale tests were conducted on State Route 14 near Palmdale, about an hour north of Los Angeles, to evaluate the fatigue behaviour of hydraulic cement concrete pavement. It was observed that there is variability in the performance of the slab, some slabs crack under very early traffic while others are long-lasting. The cause of variability might be that the concrete pavement has lost support from the substructure in turn due to cyclic variations of temperature that affect the structural behaviour of the slab due to the expansion and contraction of the slab [6]. The conventional cast-in-place method requires several days before the traffic is allowed, while the repair with fast track Portland cement concrete (PCC) also needs several hours before the lane can be open to operations. If time is the essence, then the precast technology is the suitable solution for the slab replacement. Existing pavement structure, location of the damaged portions of the pavement, the expected life of pavement, types of repair (temporary or permanent), and availability of experienced contractors and local manufacturing facilities are the essential factors that should be considered while using precast technology for the rehabilitation of pavement [7].

The significant use of precast technology is to reduce construction time in congested traffic corridors without sacrificing the quality or durability of the pavement. Consequently, it reduces 
lane closure time in heavily-trafficked areas. Precast concrete panels are fabricated in a controlled environment (field curing time is saved and requires minimal time for the component system to achieve strength), transported to the construction site, and installed on a graded foundation $[4,8]$. The installation of precast concrete panels on construction sites is shown in Figure 1.

As the precast panels are fabricated in a controlled environment, they are produced under greater control over the consistency of the concrete mix, procedures of vibration, proper curing and reduced or eliminated curling (due to moisture gradients), strength loss due to insufficient curling and air entrainment problems that are common with traditional cast-in-place concrete pavement [9]. The width of the precast panel is usually provided enough to permit multiple lanes of the existing pavement to be reconstructed simultaneously, depending on on-site access and clearance constraints. Precast panels can be used for single panel replacement or multi-panel replacement or full-width road construction. Precast concrete pavement is preferable technology for short lane closure and long-lasting pavements, short-lasting pavements are not acceptable because of economic and environmental reasons [8].
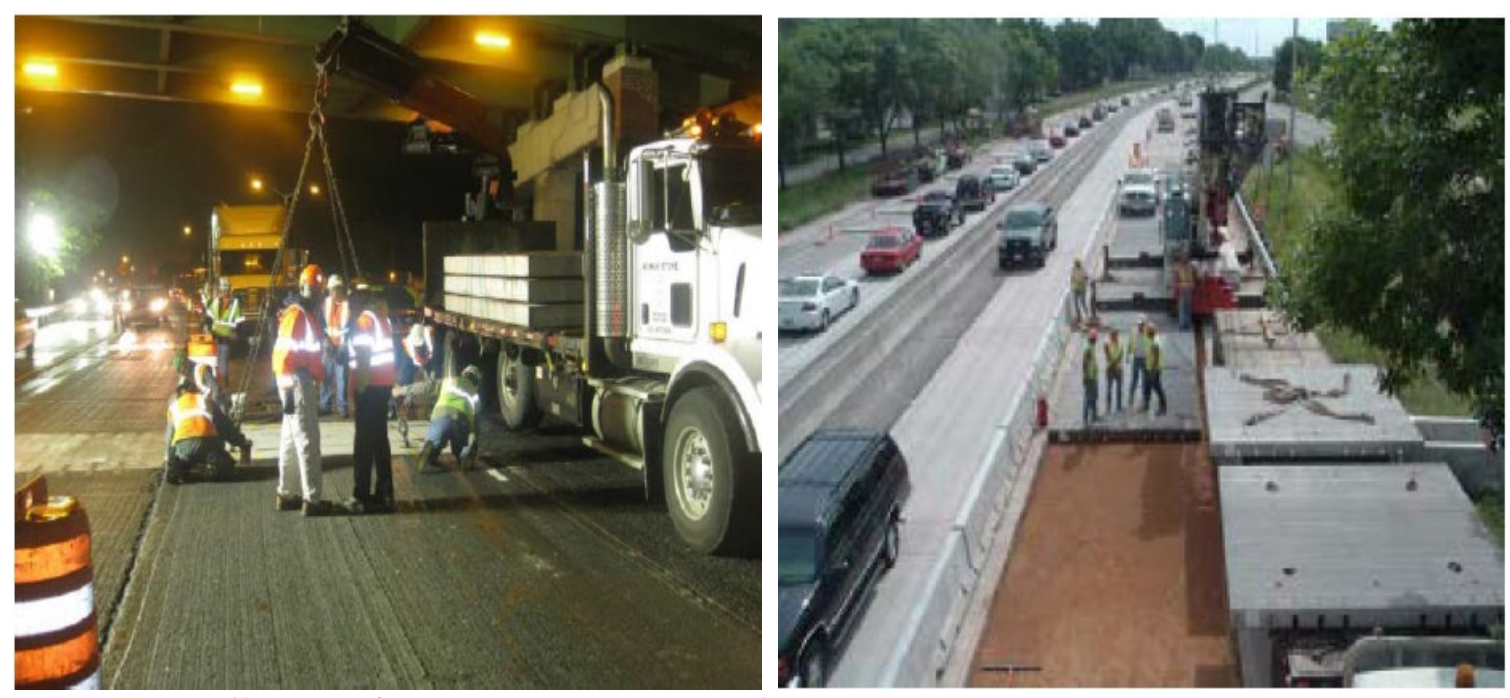

Figure 1-Installation of precast concrete panels on construction site [10]. 


\section{$1.2 \quad$ Research methodology}

The methodology adopted for the research behind this paper is illustrated in Figure 2.

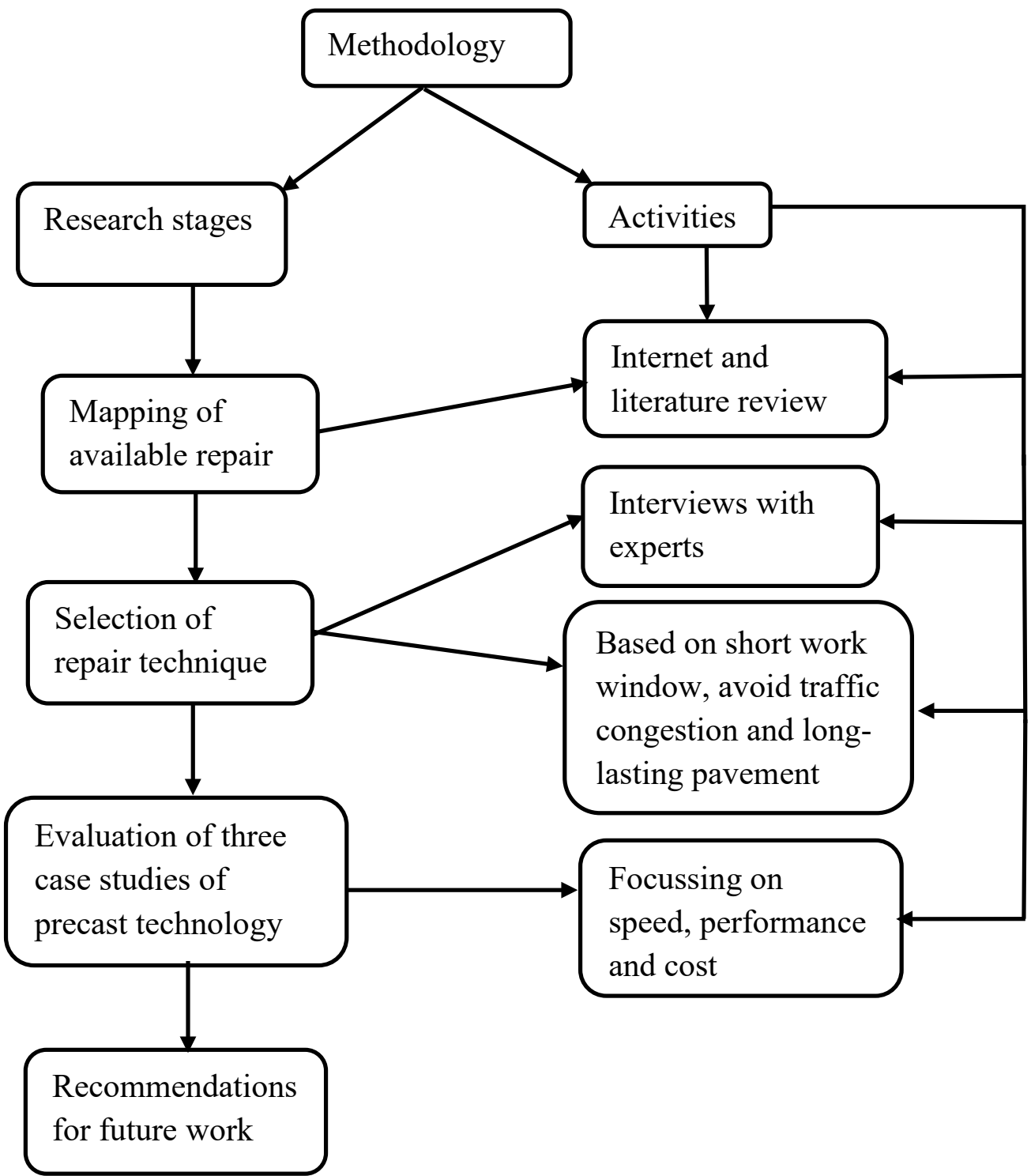

Figure 2 - Applied research methodology.

\subsection{Benefits of precast concrete pavement systems}

Better-quality concrete and curing conditions

The problem related to concrete delivery on construction sites and flooring equipment operations, including poor concrete quality, concrete consolidation and concrete surface finishing, are eliminated. One main advantage of precast technology is that curing of the precast panels takes place under controlled environmental conditions at the plant. Another one is that they are installed on the construction site during nighttime and ready to be opened to the traffic the next morning, which help to reduce the delay before opening to traffic $[4,11]$. 


\section{Speed of construction}

Precast concrete pavement has the potential of rapid construction or, more importantly, the fast opening of the pavement to traffic. The rapid-setting concrete paving mixtures require 2 to 4 hours for curing. The short closure time reduces the construction activities on-site and prevents the congestion of traffic [12].

\section{Durability or long term solution}

The primary consideration of choosing PCPS is the longevity or durability of precast concrete pavement. Precast pavement panels require little, if any, additional on-site curing time since they are cast off-site, fully cured and ready for use upon arrival [13]. The precast concrete pavement also helps to ensure the uniformity of the concrete mixture because the mixtures are transported only for a short distance between batch plant and forms. The precast concrete panels can be reinforced or prestressed. Prestressed concrete pavement systems are the attractive solution of long-term service life performance, i.e., 30 to 40 years service life. But for shortterm performance, other solutions are more cost-effective [12].

\section{Safety}

The essential advantage in the work zone of precast concrete pavement is safety. The constructions can be completed during short time closures if the construction is restricted to non-peak travel times. The safety of pavement users and construction workers is improved by reducing the frequency and duration of the work [12].

\section{Sustainability}

Precast concrete pavement systems are acknowledged to be a sustainable solution. They are helpful to reduce associated pollution and traffic congestion during construction. PCPS is fast to install, and these products are designed for long-term performance, reducing annual energy consumptions. Precast fabrication plants produce quality concrete mixtures with low water-tocementitious materials ratio and a high level of uniformity [12].

\section{PRECAST CONCRETE PAVEMENT REPAIRS}

The precast concrete pavement repairs can be divided into two categories.

1. Intermittent repair of concrete pavement

2. Continuous applications

\subsection{Intermittent repair of concrete pavement}

Isolated pavement repairs are conducted using precast concrete panels under this approach. The intermittent repairs can be divided into two possible approaches [14, 15]:

- Full-depth repairs (FDRs) are used to repair deteriorated joints or cracking. This repair technique can also be used to repair punch-outs and deteriorated cracks in continuously reinforced concrete pavements (CRCP) full- panel replacement.

- Full-panel replacement are used to replace cracked slab panels. 
Key features required for intermittent repair applications to ensure that the adequate load transfer between panels, proper installation of panels and base support under the panels must be achieved are listed below [4]. The variation of intermittent repair techniques is illustrated in Figure 3.

- Provide uniform support condition under the precast panels

- Ensure a load transfer at transverse joints

- Level the elevation differences between the panel and the existing pavement

- Ensure long-term performance of the repair

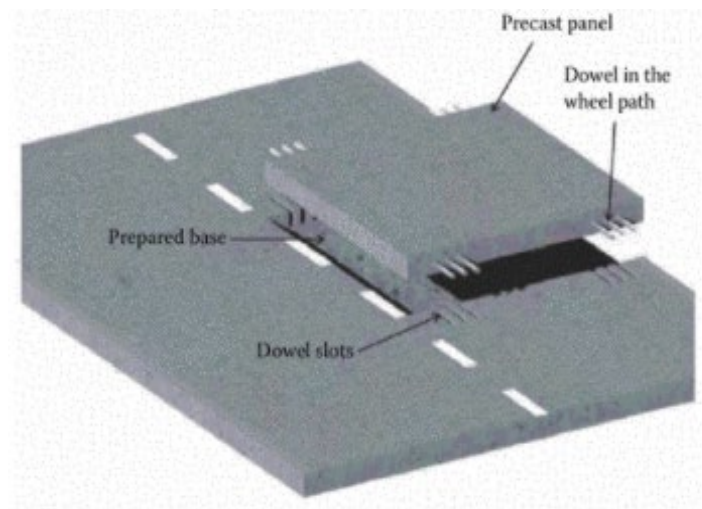

a) With slots of dowel bars cut in existing concrete pavement

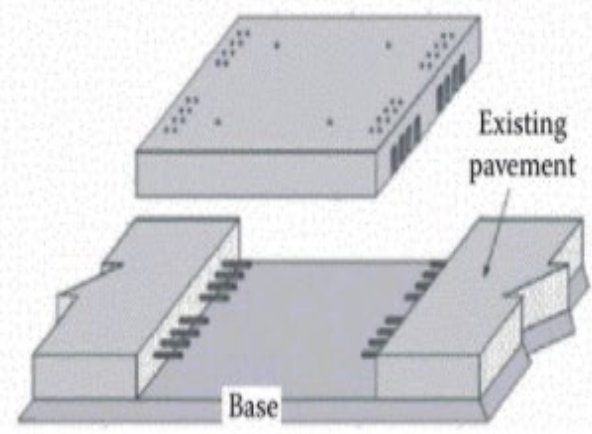

b) Dowel bars positioned in existing pavements

Figure 3 - Variation of intermittent repair technique [16].

\section{2}

\section{Continuous application}

This approach includes full-scale project-level rehabilitation (reconstruction or overlay application) of asphalt and concrete pavements using precast concrete panels. For continuous applications two types of system have been used in the United States [17, 18]:

1. Jointed precast concrete pavement (JPrCP) systems:

a. Reinforced concrete panels.

b. Prestressed (pre-tensioned) concrete panels.

2. Precast post-tensioned concrete pavement systems (PPCP)

Jointed precast concrete pavement (JPrCP) system

$\mathrm{JPrCP}$ is designed so that the precast panel expands or contracts at joints. In JPrCP, the transverse joint load transfer between the precast panels or the precast panels and the existing pavement is achieved by providing standard load transfer dowels. The width of the JPrCP panel is one lane wide (typically $3.6 \mathrm{~m}$ ) and the length is $4.8 \mathrm{~m}$ or less dependent on the type of application. The structural design of JPrCP (design of panel size, load transfer system, transverse joint spacing) is the same that of jointed cast in place concrete pavements; therefore, the designs can be performed confidently across the world. The key design and construction element in jointed precast concrete pavement is presented in Figure 4. The four basic requirements of jointed precast concrete pavement are [19]:

- Adjust the panels to the grade 
- Install bedding material to support panels uniformly.

- Establish effective load transfer between panels

- Provide a geometrically correct pavement surface (by grinding, using nonplanar panels or other means).

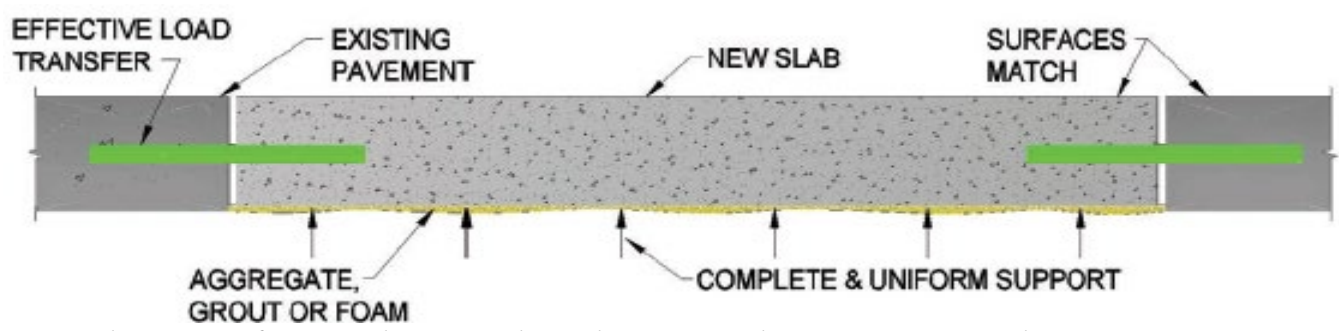

Figure 4 - Schematic figure showing key design and construction elements in a jointed precast concrete pavement panel installation [19].

Precast post-tensioned concrete pavement system (PPCP)

The main advantage of the PPCP system is that the prestressing force in the PPCP increases the panel's structural capacity that leads to possibilities to reduce the thickness of the panel, which is also safe during transportation and installation. PPCP is very useful in such circumstances where thin pavement is needed due to a high subbase layer. PPCP increases the durability of pavement and significantly reduces the maintenance cost [20] There are three different configurations of the PPCP system that are illustrated in Figure 5.

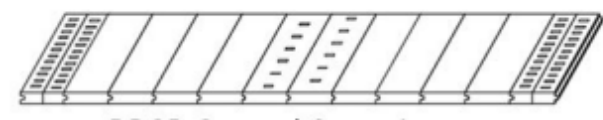

PPCP Central Stressing

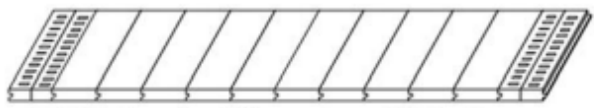

PPCP Central Stressing @ Surface

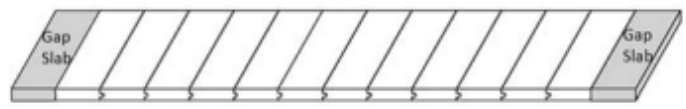

PPCP End Stressing @ Vertical Joint Face

Figure 5 - Schematic view of PPCP, different design and construction options [19].

\section{PRECAST CONCRETE PAVEMENT SYSTEM}

Many highway departments are looking for a suitable method for the rapid rehabilitation of pavement and keeping them durable. Precast concrete technology is gaining popularity among them. Several precast systems are used for both intermittent and continuous repairs. Some of them are:

- Fort Miller Super-Slab system

- Roman Stone system

- Michigan system 


\section{1}

\section{Fort Miller Super-Slab system}

A proprietary PCP technology called super-slab system is suitable for both intermittent and continuous paving operations. Super-slab is the most common method that is widely used around the world. It consists of precisely fabricated precast panels, installation methods, and materials for interlocking them together to create an integrated pavement system. With a super slab system, pavement repairs take less than an 8-hour roadway closure. To provide uniform slab support, precast panels with a thin layer of fine bedding material (maximum aggregate size $12.7 \mathrm{~mm}$ ) are installed directly on a prepared subgrade [14, 21, 22]. Dowels bars are used in the Super-Slab system to transfer the load between adjacent precast panels or between the existing pavement and precast pavement. The dowel slots are positioned in the bottom side of the SuperSlab system so that slot grout is not directly subjected to the environment (possible freeze-thaw effects, moisture, deicing salts, etc.) and not directly exposed to passing wheel loads, which might cause the material to deteriorate. A Super-Slab system can be seen in Figure 6.

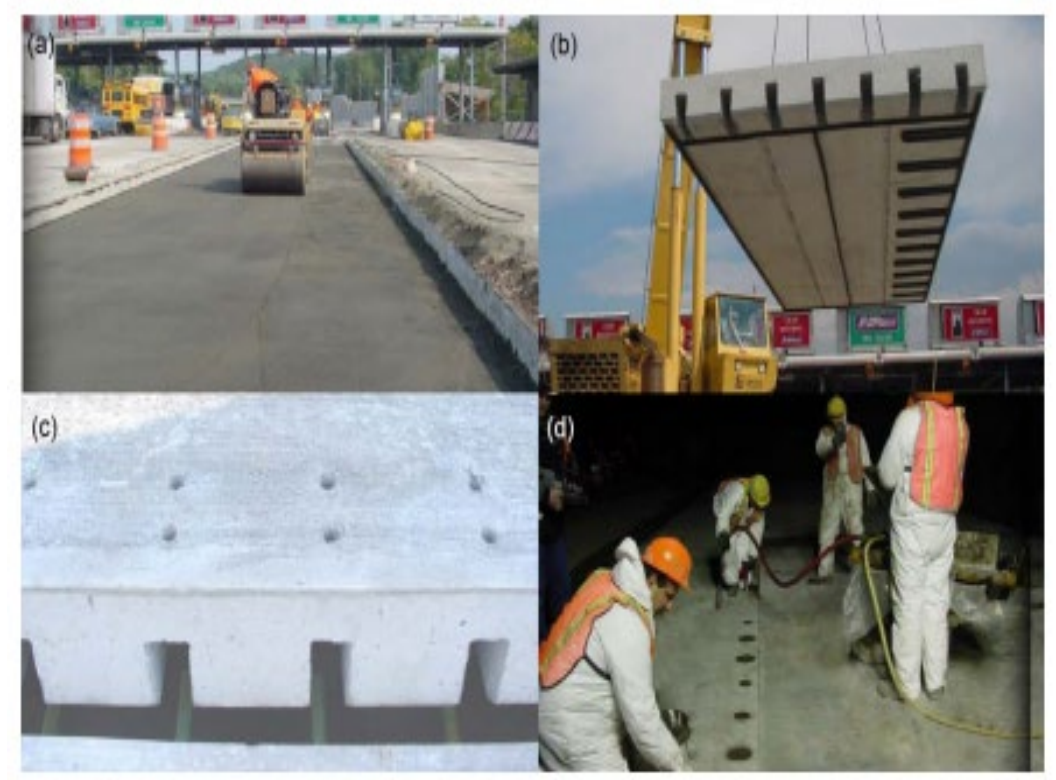

Figure 6 - Fort Millar Super Slab system (a) sub-grade preparation - bedding material; (b) panels installation; (c) interlock systems between adjacent elements; (d) dowel grout pumped into each inverted dovetail slot [21].

\section{2}

\section{Roman Stone system}

The Roman Stone construction company developed the system in 2009 for intermittent repair. The load transfer in this system is provided by the Dowel Bar Retrofit (DBR) technique after the panels are placed. The precast panels are cast less than $25 \mathrm{~mm}$ thinner than the existing pavement. The special feature of this system is to use expensive polyurethane foam under the cast panel to fill voids, and then panels are raised to the desired elevation as the foam expands $[12,23,24]$. 
The Michigan method is also known as a precast concrete panel for full-depth repair method and is used for intermittent repair. In October 2001 and summer 2002, this system was used to install 21 precast panels along two interstate roads of Michigan with the help of Michigan State University in cooperation with the Michigan Department of Transportation. The panels were sized $1.8 \mathrm{~m}$ long, $4.8 \mathrm{~m}$ wide and $250 \mathrm{~mm}$ thick. Three dowels slots were cut in the panels and $38 \mathrm{~mm}$ diameter dowels were used along the wheel path to transfer the load across joints. Flow able fill was used to fill the gap between the precast panel and base as a result of the slab demolition and removal process [25].

\section{TECHNICAL CONSIDERATIONS FOR A PRECAST CONCRETE PAVEMENT (PCP) SYSTEM}

Precast concrete pavements have common features and requirements but differ in several design aspects, i.e., panel fabrication and installation, how the load transfer is achieved at the transverse joint, and support conditions between the prepared base and the precast panel. The construction features and key design that are important for any precast concrete pavements system are as follows $[4,26,27]$.

- Concrete requirement

- Support conditions

- Load transfer at joints

- Joint spacing

- Panel reinforcement and installation rate

\subsection{Concrete requirements}

Concrete mix requirements for cast-in-place concrete and PCP are similarly specified by highway departments. Some problems associated with cast-in-place concrete can be avoided with PCP, such as early age changes in concrete volume, placement in hot or cold weather, placement in rainfall, delays in concrete delivery and equipment failure. The panel fabrication in a controlled environment is a significant advantage of PCP. Precast concrete pavement should fulfil the following concrete requirement [26]:

- Concrete strength (at 14 or 28 days)

o Flexural strength for design purposes - $650 \mathrm{psi}(4.5 \mathrm{MPa})$.

○ Compressive strength for acceptance purposes $-4000 \mathrm{psi}(27.5 \mathrm{MPa})$

- Maximum water-cementitious materials ratio- 0.45 for pavement exposed to cycles of freezing and thawing, 0.50 for other pavement

- Air content - Depend on maximum aggregate size used and extremity of exposure (climatic region)

- Durability - Concrete must be durable and not sensitive to material distress, such as alkali-silica reactivity, sulphate attack.

- Surface texture 
The compressive strength of the prefabricated panel is also an essential factor to take into account when stripping panels. The panels are typically stripped after 16 hours of casting and compressive strength at the time of stripping should be at least 17.2 MPa (2500 psi). To achieve rapid strength gain many precasters utilize steam curing.

\section{2}

\section{Support conditions}

The bedding layer between the precast panel and base provides support for PCP and it depends on how the panels are installed. The panel installation is done either on grade-supported system or on grout-supported system. In a grade supported system, the bedding layer (consists of a thin layer of cemented granular material, typically $13 \mathrm{~mm}$ ) is placed over the graded and compacted base. In the grout supported system, the panels are set over the base using Garcia levelling screws and fast setting flowable fill grout (typically 6 to $13 \mathrm{~mm}$ ) is introduced through grout ports at the panel surface to fill the gap between the base and the panel [26]. The grade supported and grout supported panel placements are illustrated in Figure 7.

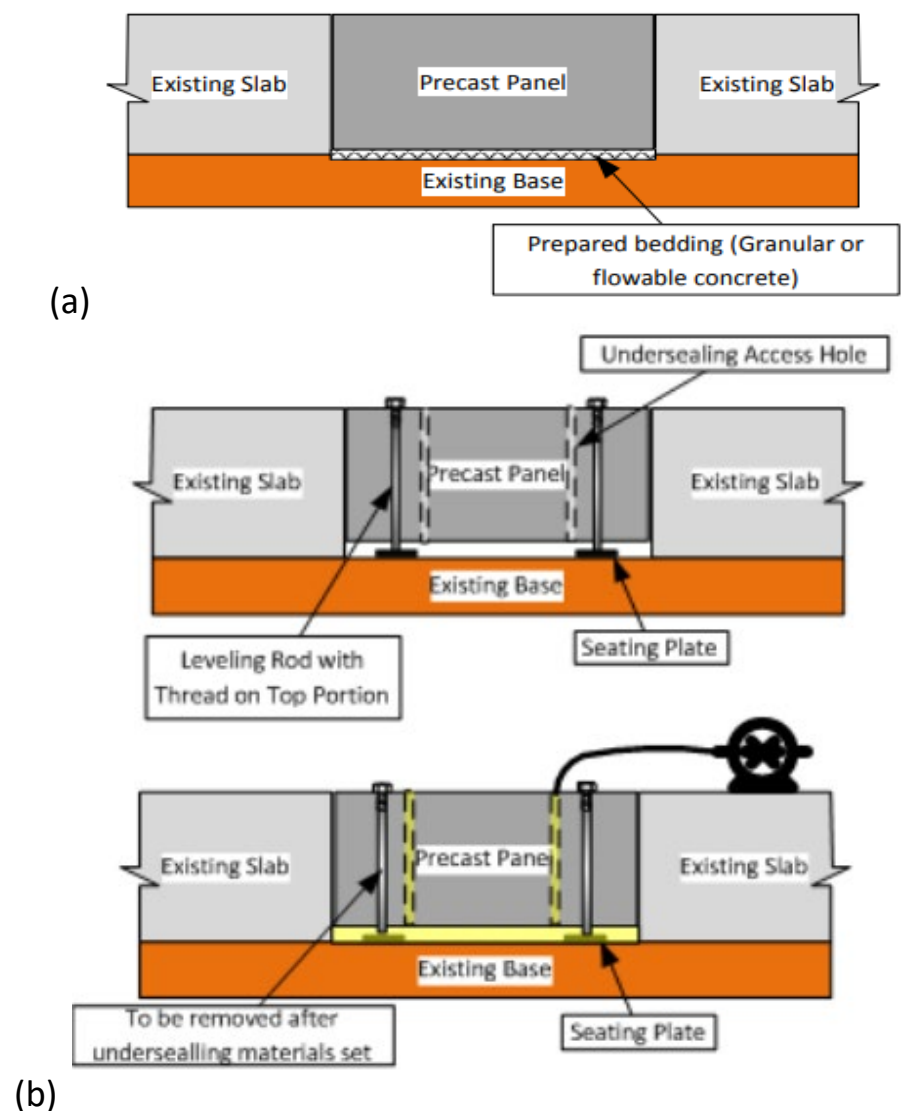

Figure 7 - Support conditions (a) Grade-supported panel placement (b) Grout supported panel placement [28].

Sub-sealing is performed in grade supported system to fill the void between panel and base. The compressive strength of both bedding material and sub-sealing material at the time of opening traffic should be $3.5 \mathrm{MPa}(500 \mathrm{psi})$ and about $17.2 \mathrm{MPa}(2500 \mathrm{psi})$ at 28 days [29,30] To meet the smoothness requirement, the panel surface level can be adjusted to match with the adjacent pavement surface; therefore, surface grinding may not be necessary for grout supported systems but it is almost always required in grade supported systems [18]. 
Load transfer at transverse joints is another important consideration for jointed precast concrete pavements. Dowel bars are used along the transverse direction to transfer load to adjacent panels similar to the DBR technique in existing pavement. Typically, in Jointed Precast Concrete pavement (JPCP) the dowel bars installed in slots or ducts are fabricated along one transverse side of the panel. The most common systems used in U.S associated with the dowel bar slots are (i) dowels bar slots at the panel bottom (ii) narrow-mouth dowel bar slots at the panel top surface (iii) teardrop-shaped surface slot (iv) Barra Glide load transfer system as shown in Figure 8 [26-28].

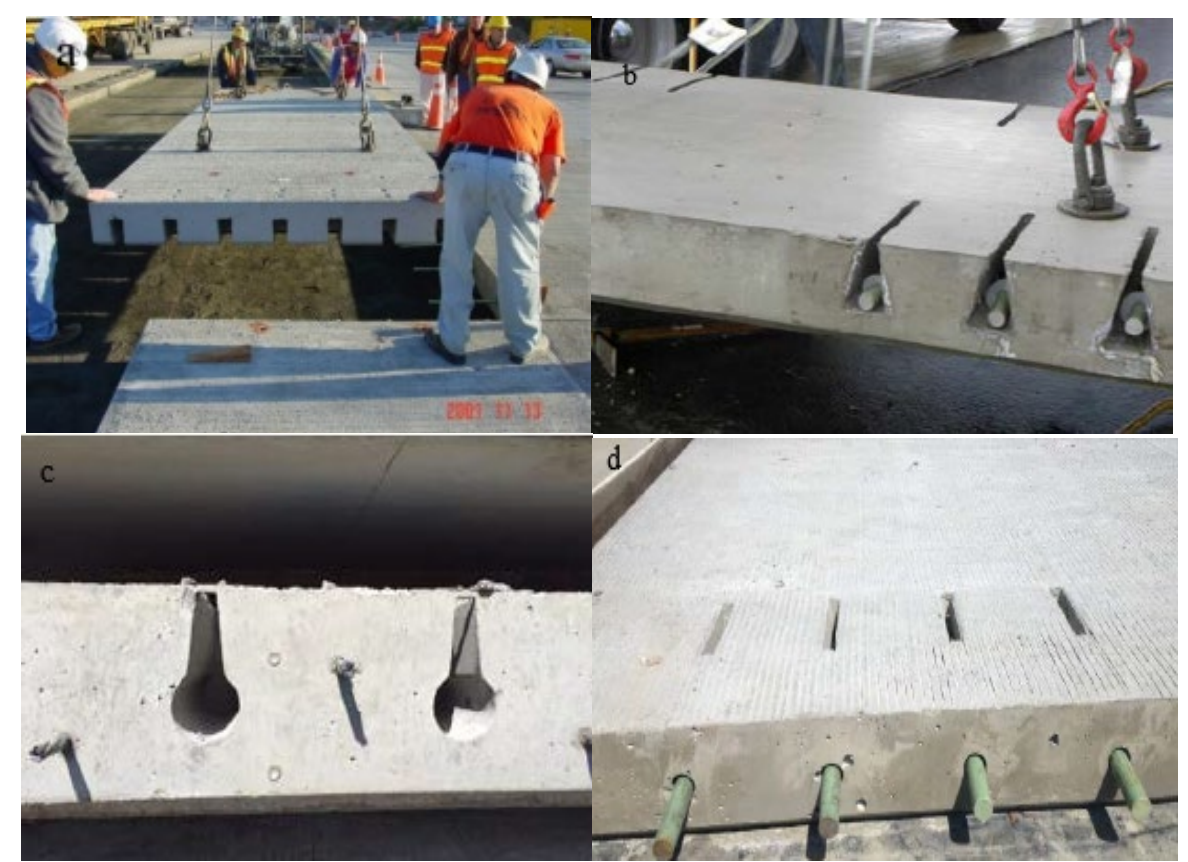

Figure 8-Different dowel system a) Super-Slab system (b) narrow mouth slots (c) tear-drop shaped system (d) Bara Glide dowel system [28].

Due to expansion and contraction, the system must allow transverse joints for proper opening and closing to maintain load transfer efficiency (LTE). Following are the critical aspects of dowel bars in PCP system for long term performance [26]:

- Dowel bar: Dowel diameter $32 \mathrm{~mm}$ is recommended for precast panel less than $250 \mathrm{~mm}$ thick and diameter $38 \mathrm{~mm}$ is recommended for slab thickness between 250 and $360 \mathrm{~mm}$.

- Dowel length: The location of dowel bar is sensitive in JPCP; therefore, 355- to 380-mm long dowel bars are considered adequate for a joint width of up to $12 \mathrm{~mm}$, allowing for embedment of about $178 \mathrm{~mm}$ at each side of the joint.

- Dowel spacing: The dowel bars can be spaced at $300 \mathrm{~mm}$ over the entire length of joints for both intermittent and continuous repairs, but four dowel bars per wheel path are considered adequate for traffic channelization. 
- Dowel patching material or grout: The compressive strength of patching material or grout for dowel bars and lifting insert ports at the time of opening to traffic should be 17.2 $\mathrm{MPa}(2500 \mathrm{psi})$ about $27.6 \mathrm{MPa}(4000 \mathrm{psi})$ at 28 days.

- Dowel bar location and alignment: Ideally, the dowels are placed at the mid-depth of the panel and parallel to longitudinal axis of pavement to avoid horizontal translation, vertical translation, longitudinal translation (also called "side shift"), horizontal skew and vertical tilt [29].

\subsection{Joint spacing}

One of the main design parameters of the JPCP is joint spacing. For intermittent repair, the length of the JPCP panel is approximately $1.8 \mathrm{~m}$ or full length with typically single-lane width. For continuous repair, the length of the JPCP ranges from 3.3 to $4.8 \mathrm{~m}$ for thick panels with single or two-lane width. Shorter panels are useful for monitoring joint distress in case of intermittent repairs [18]. In Sweden, the JPCP panel length is limited to $5 \mathrm{~m}$ with lane width of $3.5 \mathrm{~m}[30]$.

\subsection{Panel reinforcement and installation rate}

In jointed precast concrete pavements, to avoid cracking due to lifting, transporting and installation operations, double mat (top and bottom) reinforcement is provided i.e. $0.2 \%$ of the cross-sectional area. The provided reinforcement will not have any substantial effect on the structural performance of the slab.

The panel installation rate is the most critical factor for the precast concrete technology and it depends upon the lane closure, traffic congestions and site clearance. With good lane closure requirement for intermittent repairs, typically 15-20 panels can be installed per nighttime lane closure and for continuous repair 40-50 panels can be installed per nighttime closure [24].

\section{CASE STUDIES ON PRECAST CONCRETE PAVEMENT REPAIRS}

Three case studies have been chosen for investigating the repair of concrete pavement using jointed precast concrete panel in more detail. The first case study is related to the highway pavement, which provides the details of PCP implementation on the rehabilitation of concrete pavement in the heavily trafficked area. The second and the third case studies are related to the airfield pavement and are based on the speed of precast concrete technology. In addition to the third case study, the cost of PCP was compared with previously used other repair types.

\section{1}

\section{Case study 1: Honolulu Interstate H1 precast concrete pavement demonstration project}

The Hawaii Interstate H1, a demonstration project of PCP, was conducted in 2016 by the Hawaii Department of Transportation (DOT). The Interstate H1 is located just east of the Aiea Pedestrian Overpass and parallel to Heleconia place. The eastbound lanes carry high traffic during the morning rush hour i.e. annual average daily traffic (AADT) between 90,000 and 
200,000 vehicles, therefore to rehabilitate the settled section Hawaii DOT uses PCP to provide a long term solution. The project was consisted of the replacement of six lanes of settled jointed concrete pavement. The Super Slab panels were dimensioned 305 x 305 x 255 mm with Barra Glide slots and were installed using Garcie levelling lifts. The Barra Glide load transfer system can be seen in Figure 9.

Total 84 panels were cast over a period of 30 days with 3000 man-hours to complete the rehabilitation of interstate H1. Due to the limited availability of slot blockouts, only six panels were fabricated at a time and seven panels were installed per night lane closure. The panel installation included the removal of existing pavement, preparing the cement-treated base, panel setting, levelling and grouting. Saw cutting of the existing pavements was done in advance one or two nights before the panel installation. To achieve the desired compressive strength of concrete- mix ready, the delivered concrete was tested on a daily basis. Performance plus RH bedding grout was used to fill the small voids between base and precast panel while Performance Plus RH Latex fill grout was used to fill the dowel slots. Both grouting materials were rapid hardening, very free-flowing, zero bleed, sand free and cementitious grout. For details, see in [31].

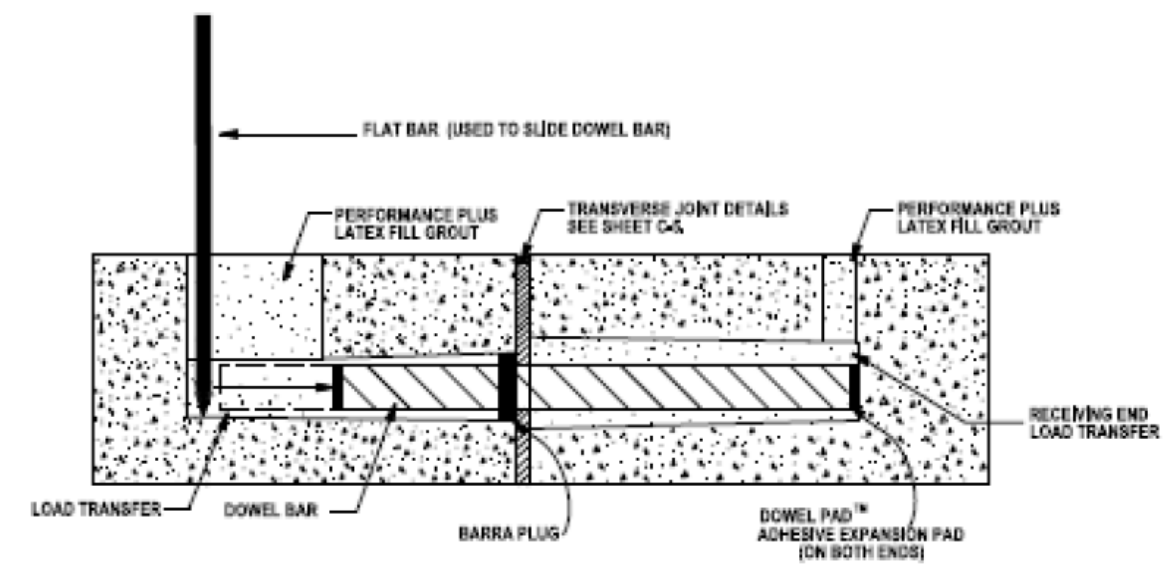

Figure 9 - The Barra Glide load transfer system after the dowel [31].

5.2

Case study 2: Precast concrete paving repairs at Vancouver International Airport

In 2019, Vancouver International Airport (YVR) conducted a precast concrete panel replacement using the proprietary Super-Slab ${ }^{\circledR}$ system on Taxiway Victor to establish whether precast concrete was a viable option for a planned runway repair project. This was the first major use of precast airfield pavement in North America in nearly 20 years. The pilot project was conducted to replace twelve precast panels on Taxiway Victor, measuring $6 \mathrm{~m} \times 7.5 \mathrm{~m}$ with a thickness of $360 \mathrm{~mm}$. To provide visual aids for aircraft operation, 5 out of 12 panels required light cans, which required significant precision for proper alignment and functioning. The new improved and innovative technologies of the $21^{\text {st }}$ century of the precast concrete pavement were involved in this project.

To avoid disturbance of support layers, the precast panel's thickness was limited to $360 \mathrm{~mm}$, and $20 \mathrm{~mm}$ bedding layer was used between the precast panel and the existing cement stabilized base. Due to precast panel thickness limitation, the structural design requirements were achieved 
by reinforcing the panels with 20 and $25 \mathrm{~mm}$ bars with approximately $135-200 \mathrm{~mm}$ spacing in the top and bottom mats and additional steel around the slab perimeter and in the corners. The installation of the panels was decided to complete over three nights for more (eight hour night closure time), for details see in [32]. The installation of Super Slab panel on the construction site can be seen in Figure 10.

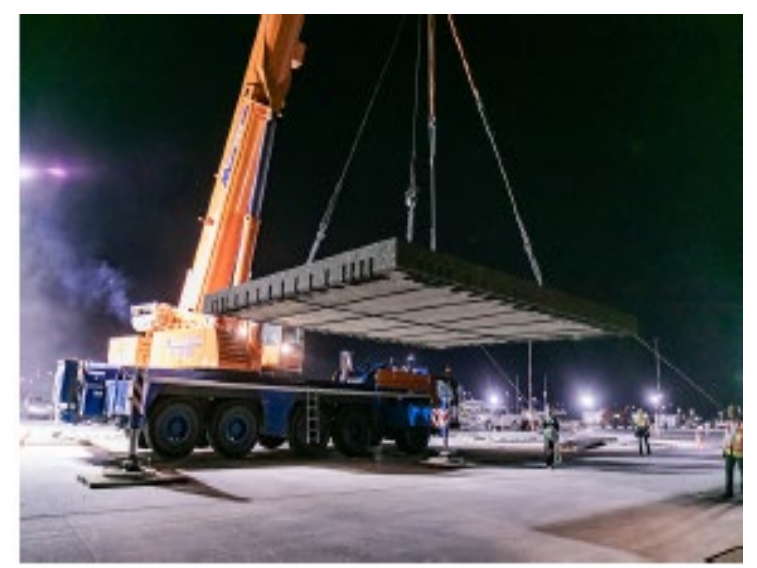

Figure 10 - Installation of a typical Super-Slab panel at YVR, showing dovetail edge slots to accommodate dowels anchored in adjacent panels, bottom-mounted foam grout containment gaskets, and bedding grout distribution channels [32].

\section{3}

\section{Case study 3: Full-Scale field testing of precast Portland cement concrete panel airfield pavement repairs}

The United States conducted research to determine the feasibility of rapid repair using precast technology in 2011. The purpose of the study was to develop a precast Portland cement concrete panel repair system to conduct expedient airfield pavement repairs for military operations worldwide. For this, three types of repairs were conducted i.e. Repair 1 (single panel), Repair 2 (two panels) and Repair 3 [Quad panels (four panels)]. The intent was to determine if precast panel repairs could be completed within a 4 to 6-hour timeframe and to support aircraft traffic i.e., minimum pass levels of 3700 passes of $\mathrm{C}-17$ aircraft traffic before failing. Later, the performance, speed and cost of precast panel was compared with other repair methods.

The study focused on replacing full-slab replacement i.e. $355 \mathrm{~mm}$ thick PCC pavement, using precast panels with thickness $280 \mathrm{~mm}$ and $75 \mathrm{~mm}$ flowable fill between the base course and precast panel. Two types of panels were designed to enable both single repair and multi-panel repair, named standard panel and terminal panel. The standard panel had load transfer on both transverse edges, while the terminal panel had load transfer on one transverse edge, see Figure 11. 


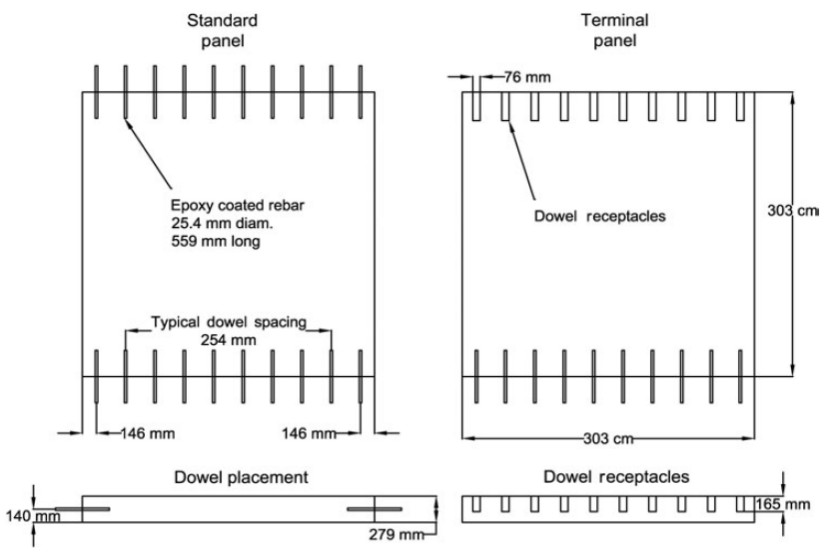

Figure 11 - Panel Schematics [33].

The size of the partial slabs were with a single panel $3 \mathrm{~m} \times 3 \mathrm{~m}$, half slab replacement with two panels $3 \mathrm{~m} \times 6.1 \mathrm{~m}$ and full slab replacement with four panels was $6.1 \mathrm{~m} \times 6.1 \mathrm{~m}$. The panels were minimally reinforced with top and bottom mat $9.5 \mathrm{~mm}$ diameter bar and two layers of $16 \mathrm{~mm}$ bar all around the panels to avoid installing and storage damage of panels. The comparison of precast concrete panel with other methods is shown in Table 2. The individual installation time for each precast panel time is illustrated in Table 3. For more details see [33].

Table 2: Comparison of precast concrete panel with other methods (based on time to complete single panel) [33]

\begin{tabular}{|c|c|c|c|c|}
\hline Repair type & Repair detail & $\begin{array}{c}\text { Passes to } \\
\text { failure (\#) }\end{array}$ & $\begin{array}{c}\text { Time to } \\
\text { complete } \\
\text { repair (h) }\end{array}$ & $\begin{array}{c}\text { Estimated } \\
\text { material cost } \\
\text { (US \$) }\end{array}$ \\
\hline Rapid-setting cap/aggregate & $\begin{array}{c}254 \mathrm{~mm} \text { cap } \\
102 \mathrm{~mm} \text { compacted } \\
\text { aggregate }\end{array}$ & $5000+$ & $3.5 \mathrm{~h}$ & 1380 \\
\hline Rapid-setting cap/foam & $\begin{array}{c}254 \mathrm{~mm} \text { cap } \\
102 \mathrm{~mm} \text { foam }\end{array}$ & 1000 & $3.2 \mathrm{~h}$ & 6055 \\
\hline Rapid-setting cap/injected \\
foam & $\begin{array}{c}254 \mathrm{~mm} \text { cap debris } \\
102 \mathrm{~mm} \text { foam }\end{array}$ & 1000 & $3.8 \mathrm{~h}$ & 6020 \\
\hline Rapid-setting cap/flowable \\
fill & $\begin{array}{c}254 \mathrm{~mm} \text { cap } \\
102 \mathrm{~mm} \text { flowable fill }\end{array}$ & $5000+$ & $3.4 \mathrm{~h}$ & 1865 \\
\hline Precast panel/flowable fill & $\begin{array}{c}279 \mathrm{~mm} \text { panel } \\
76 \mathrm{~mm} \text { flowable fill }\end{array}$ & $5000+$ & $4.8 \mathrm{~h}{ }^{\mathrm{a}}$ & 2500 \\
\hline Traditional PCC (full-depth) & $356 \mathrm{~mm}$ PCC & $5000+$ & 28 days & 555 \\
\hline
\end{tabular}

${ }^{\mathrm{a}}$ Based on time to complete a single-panel repair. 
Table 3: Precast panel installation time [33]

\begin{tabular}{|c|c|c|c|}
\hline Task & \multicolumn{3}{|c|}{ Time (min) $^{\mathrm{a}}$} \\
\cline { 2 - 4 } & $\begin{array}{c}\text { Single-panel } \\
\text { repair }\end{array}$ & $\begin{array}{c}\text { Double-panel } \\
\text { repair }\end{array}$ & $\begin{array}{c}\text { Quad-panel } \\
\text { repair }\end{array}$ \\
\hline Mark perimeter of distressed slab & 10 & 15 & 20 \\
\hline Saw-cutting operations & 15 & 35 & 60 \\
\hline Dowel slot cutting & 25 & 50 & 50 \\
\hline Anchor drilling and installations & 20 & 40 & 80 \\
\hline Attach crane rigging hardware & $0^{\mathrm{b}}$ & $0^{\mathrm{b}}$ & 5 \\
\hline Lift distressed section & 5 & 10 & 20 \\
\hline Dowel slot excavation (existing PCC slab) & 30 & 60 & 60 \\
\hline Flowable fill placement & 10 & 20 & 25 \\
\hline Precast panel placement & 5 & 10 & 30 \\
\hline Compaction (if needed) & 5 & 10 & 20 \\
\hline Removal of flowable fill from dowel slots & 5 & 5 & 10 \\
\hline Placement of joint and dowel sealant & 30 & 55 & 90 \\
\hline Dowel slot finishing & 5 & 10 & 20 \\
\hline Curing & 120 & 120 & 120 \\
\hline Total repair time(min) & 285 & 440 & 610 \\
\hline Total repair time (h) & 4.75 & 7.33 & 10.17 \\
\hline
\end{tabular}

${ }^{\mathrm{a}}$ Times rounded to the nearest $5 \mathrm{~min}$ interval. $\quad{ }^{\mathrm{b}}$ Task required less than $1 \mathrm{~min}$ to complete.

6.

\section{SUMMARY}

The issues associated with the traditional cast-in-place concrete pavement repair may be eliminated with new repair technology, i.e., precast concrete pavement. Precast concrete technology is used for any type of application where expedient pavement repairs are required. The application includes the removal and replacement of pavement or new pavement applications, intersections and ramps. The precast concrete panels are fabricated in a controlled environment which improved the repair quality of pavement as well as improved potential for long-lasting repairs. In addition, precast concrete pavement is a suitable technology for applications requiring a short pavement closure time.

Following conclusions are obtained by analysing the above three case studies using jointed precast concrete panel as repair applications. Furthermore, the comparison among three case studies i.e. Honolulu Interstate H1 precast concrete pavement demonstration project, precast concrete paving repairs at Vancouver International airport, full-scale field testing of precast Portland cement concrete panel airfield pavement repairs are illustrated in Table 4.

- The Hawaii Interstate H1 is a successful demonstration project of PCP technology which provides the detailed implementation of PCP. The interstate $\mathrm{H} 1$ is heavily trafficked area therefore PCP is the best alternative to minimise the traffic lane closure and provide a long-term solution. The project was extended from few weeks to several months during installation period because of shortage of bedding grout. But after the availability of bedding grout the project progressed smoothly. The concrete used in this project was able to achieve compressive strength more than $21 \mathrm{MPa}(3000 \mathrm{psi})$ at 24 hours and 41 $\mathrm{MPa}(6000 \mathrm{psi})$ at 28 days. The bedding grout achieved compressive strength of $17 \mathrm{MPa}$ 
(2500 psi) at 24 hours and $55 \mathrm{MPa}(8000 \mathrm{psi})$ at 28 days while the dowel bars slots grout material achieved $21 \mathrm{MPa}(3000 \mathrm{psi})$ within one hour and $55 \mathrm{MPa}(8000 \mathrm{psi})$ at 28 days.

- The Vancouver International airport pilot project was the demonstration and development of a large size precast panel in 8-hours overnight work windows on an active airfield that addressed heavy anticipated load and limited the thickness of the panel. The project was conducted in 2019 and is still in use, confirming jointed precast concrete pavement's durability at least two years of performance during an 8-hours overnight work window. Dowel bar conflict, the bond between cement stabilized base and existing slab and tight constructions tolerance was major challenges in the YVR pilot project. The pilot project consists of only 12-panels replacement; therefore, the precast panel's production efficiencies and repairs cost and associated closure window time with conventional repair were not performed. The case study showed that the overall production efficiency of the precast panel can be achieved by using specially trained crew members and keep them together.

- In full-scale field testing of precast Portland cement concrete panel airfield pavement repairs, the precast repair method's time, cost, and performance were compared with other repair methods to determine the feasibility of using a new repair method against others previously tested. It was noticed that the only single panel repair might be conducted in less than 6 hours while the others might be conducted in 8 to 10 hours. All the repair types were withstood 5000 passes except the repair method with foam and injected foam. The precast slab was the third-best option to consider for rapid repair in terms of cost, performance and time; see Table 1. Traditional PCC was the least expensive option, but an immediate return to the traffic was not possible with this method. 
Table 4: Comparison of jointed precast concrete pavement among three case studies i.e. Honolulu Intestate H1 precast concrete pavement, Vancouver International airport, full-scale and field testing of precast Portland cement concrete panel airfield pavement repairs

\begin{tabular}{|c|c|c|c|}
\hline Parameters & Case study 1 & Case study 2 & Case study 3 \\
\hline Construction year & 2016 & 2019 & 2011 \\
\hline Types of Repair & Continuous & Intermittent & $\begin{array}{c}\text { Intermittent and } \\
\text { continuous }\end{array}$ \\
\hline Size & $3.6 \mathrm{~m} \times 3.6 \mathrm{~m}$ & $6 \mathrm{~m} \times 7.5 \mathrm{~m}$ & $\begin{array}{c}\text { Repair1: Single panel- } \\
\text { 3m x3m , Repair 2: Two } \\
\text { panel: 3mx } 6.1 \mathrm{~m} \& \\
\text { Repair 3: four panels } 6.1 \\
\text { m x6.1m }\end{array}$ \\
\hline $\begin{array}{l}\text { Thickness of } \\
\text { precast panel }\end{array}$ & $255 \mathrm{~mm}$ & $360 \mathrm{~mm}$ & $280 \mathrm{~mm}$ \\
\hline $\begin{array}{l}\text { Thickness with } \\
\text { traditional PCC }\end{array}$ & $230 \mathrm{~mm}$ & $450 \mathrm{~mm}$ & $356 \mathrm{~mm}$ \\
\hline Application area & Highway & Air field & Air field \\
\hline \multirow[b]{2}{*}{ Considered loads } & AADT & A380 bus & $\mathrm{C}-17$ \\
\hline & Axle load spectra & $\begin{array}{l}\text { Max take-off weight: } \\
5730 \mathrm{kN}[34]\end{array}$ & $\begin{array}{l}\text { Max take-off weight: } \\
2600 \mathrm{kN}[35]\end{array}$ \\
\hline $\begin{array}{l}\text { Lane closure time } \\
\text { (planned) }\end{array}$ & $\begin{array}{l}\text { Day and night-time } \\
\text { lane closure, for } \\
\text { detailed see[31] }\end{array}$ & $\begin{array}{c}8 \text { hours -night-time } \\
\text { lane closure (3- } \\
\text { nights })\end{array}$ & $\begin{array}{l}\text { All repairs were expected } \\
\text { to be complete within } 4-6 \\
\text { hours }\end{array}$ \\
\hline $\begin{array}{l}\text { Lane closure time } \\
\text { (actual) }\end{array}$ & $\begin{array}{l}\text { Rehabilitation was } \\
\text { done according to the } \\
\text { planned time }\end{array}$ & $\begin{array}{l}\text { Rehabilitation was } \\
\text { done according to } \\
\text { the planned time }\end{array}$ & $\begin{array}{c}\text { Repair1: less than } 6 \\
\text { hours } \\
\text { Repair 2: } 8 \text { hours \& } \\
\text { Repair 3:10 hours }\end{array}$ \\
\hline
\end{tabular}

7.

Asphalt roads take less time to build and construction cost is low compared to concrete roads, but asphalt pavement is not a durable and economical solution for long-lasting pavements, especially for regions subjected to harsh environmental conditions. Potholes are common on asphalt roads and this leads to pavement's maintenance several times, which ultimately lead to increased costs over time. Concrete is a long-lasting or durable material and construction cost for the concrete pavement is high but has a lower maintenance cost than asphalt pavements. The pavement rehabilitation with precast concrete technology reduces the maintenance cost and overall repair time for a project. This innovative technology can be used in any weather condition (rainy or cloudy), which minimises the risk of delay of projects The highway agencies cannot afford to close lanes in traffic congestion areas to rehabilitate pavements, as these activities can only be done during a short night-time work window with precast technology. The investigation shows that the precast concrete pavement is the suitable solution for rapid rehabilitation of pavement in terms of cost, performance (panels can be thinner than conventional cast-in-place concrete). Furthermore, the required amount of time to re-open the pavement to traffic is dramatically reduced with jointed precast concrete panels.

The recommendation for future work is to develop porotypes prefabricated concrete panels and evaluate them according to Swedish conditions that include geology, climate, weather, concrete 
recipe, pavement thickness, studded tire effect, views on the environment and construction practices.

\section{ACKNOWLEDGEMENTS}

The Swedish Transport Agency (Trafikverket) is acknowledged for funding the project "The Rapid Repair of Concrete Pavements".

\section{REFRENCES}

1. Silfwerbrand J: "The Advantages of Concrete Pavements in Tunnels". Proceedings, 12th International Symposium on Concrete Roads, Prague, 2014.

2. Silfwerbrand J: "Not concrete or asphalt but concrete and asphalt- A discussion based on Swedish pavements". Proceedings, 11th International Conference on Concrete Pavements, San Antonio, Texas, USA, August 28-31, 2016, pp. 609-619.

3. Strömberg L.: "Making Concrete Pavements Competitive by Using the Standardized Framework for Comparisons of Infrastructure Projects in Terms of Cost-Efficiency and Climate Impact". Nordic Concrete Research, Vol. 62, No. 1, 2020, pp. 21-39.

4. Tayabji S, Ye D \& Buch N: "Precast Concrete Pavements: Technology Overview and Technical Considerations". PCI journal, Vol. 58, No. 1, 2013.

5. Petersson Ö \& Sundbom S: "Uppföljning av betongvägen Heberg-Långås, byggnadsrapport 1993 - Betongmaterial och fogar". ("Documentation of the concrete road Heberg-Långås, construction report 1993 - Concrete materials and joints"). CBI Commission Report, Swedish Cement \& Concrete Research Institute, Stockholm, 1994. (In Swedish).

6. Kohler E, Du Plessis L, Harvey J \& Motumah L: "Comparison of Precast and Cast-inPlace Concrete Pavements Responses under Heavy Vehicle Simulator Loads". Proceedings, 8th International Conference $\left(B C R 2 A^{\prime} 09\right)$, Univ. of Illinois at UrbanaChampaign, Champaign, , 2009.

7. Olidis C, Swan D.J, Saeed A, Mellerski C.R \& Hammons M. I: "Precast Slab Literature Review Report: Repair of Rigid Airfield Pavements Using Precast Concrete Panels-A State-of-the-Art Review", 2010.

8. Tayabji S, Ye D \& Buch N: "Performance of precast concrete pavements". Proceedings, First Congress of Transportation and Development Institute, Chicago, Illinois, USA, 2011.

9. $\quad$ Tomek R.: "Advantages of precast concrete in highway infrastructure construction". Procedia engineering, Vol. 196, 2017, pp. 176-180.

10. Tayabji S: "Precast Concrete Pavement Practices Overview". Proceedings, Indiana DOT Precast Concrete Pavement Forum, Indianapolis, Indiana, USA, August 11, 2016.

11. Singh A \& Ray D.S: "Study and Evaluation of Precast Concrete Pavement". International Journal of Engineering Science and Computers, 2019.

12. Federal Highway Administration (FHWA),"State-of-the-Art Report on Precast Concrete Pavements", Chicago, Illinois, USA, 2012, pp (1-2 )-(1-6).

13. Tayabji S, Buch N \& Kohler E: "Precast Concrete Pavements: Current Technology and Future Directions". Proceedings, 9th International Conference on Concrete Pavements International Society for Concrete Pavements, San Francisco, California, USA, 2008. 
14. Tayabji S, Buch N \& Kohler E: "Precast concrete pavement for intermittent concrete pavement repair applications". Proceedings, National conference on preservation, repair, and rehabilitation of concrete pavements, St. Louis, Missouri, USA, 2009.

15. Tayabji S: "Precast Concrete Pavement Technology (Desk Scan, American Trade Initiatives)", U.S. Department of Transportation, Federal Highway Administration, American Association of State Highway and Transportation, Washington, D.C., USA, 2010.

16. Mallick Rajib B \& El-Korchi T: "Pavement Engineering: Principles and Practice". 3rd ed, 2018. CRC Press, pp. 549-554.

17. Tayabji S, Ye D \& Buch N: "Joint Load Transfer and Support Considerations". SHRP 2 Report S2-R05-RR-1: Precast Concrete Pavement Technology, 2012.

18. Tayabji S: "Jointed Precast Concrete Pavement: Design, Specification, and Installation", 2020.

19. Smith P \& Snyder M. B: "Manual for Jointed Precast Concrete Pavement", NPCA Manual for Jointed Precast Concrete, 3rd ed, 2019.

20. Merritt D.K, McCullough B.F \& Burns N.H:"Precast Prestressed Concrete Pavement Pilot Project near Georgetown, Texas". Transportation research record, Vol. 1823, No. 1, 2003, pp. 11-17.

21. Novak J, Kohoutková A, Kř́stek, V \& Vodička J: "Precast concrete pavement-systems and performance review". Proceedings, IOP Conference Series: Materials Science and Engineering. 2017, IOP Publishing.

22. Super-slab http://www.super-slab.com/

23. Priddy L.P: "Evaluation of Precast Portland Cement Concrete Panels for Airfield Pavement Repairs". Virginia Polytechnic Institute and State University, Blacksburg, USA, 2014.

24. Tayabji S \& Ye D: "Precast Concrete Pavement Innovation, Performance and Best Practices". Proceedings, 12th International Symposium on Concrete Roads, Prague, Czech Republic, 2014.

25. Buch N, Barnhart V \& Kowli R: "Precast Concrete Slabs as Full-Depth Repairs: Michigan experience". Transportation research record, Vol. 1823, No. 1, 2003, pp. 5563.

26. Tayabji S: "Precast Concrete Pavement Technology Implementation", Federal Highway Administration. Office of Infrastructure, Washington, D.C., USA, 2019.

27. Tayabji S \& Tyson S: "Precast Concrete Pavement Innovations: Performance and Best Practices". Conference Paper, 2014.

28. Tayabji S \& Brink W: "Precast Concrete Pavement Bedding Support Systems: [techbrief]". Federal Highway Administration, Washington, D.C., USA, 2015.

29. Tayabji S: "Guide Specification for Jointed Precast Concrete Pavement Introduction [techbrief]". Federal Highway Administration, Washington, D.C., USA, 2019.

30. Tayabji S: "Overview of Precast Concrete Pavement Practices \& Recent Innovations". Proceedings, American Concrete Institute Spring Convention, Milwaukee, Wisconsin, USA, 2016.

31. Tayabji, S \& Brink W: "Load Transfer Systems for Jointed Precast Concrete Pavements". Federal Highway Administration, Washington, D.C., USA, 2015.

32. Federal Highway Administration (FHWA), "Technical Advisory of Concrete Pavement Joints", T 5040.30, Washington, D.C., USA, 2019.

33. AB Svensk Byggtjänst :"Betong på mark (Handbok)". ("Concrete slabs on grade [Handbook]"), 2002, Stockholm, Sweden, 253 pp. (In Swedish).

34. Tayabji S: "Honolulu Interstate H1 Precast Concrete Pavement Demonstration Project", United States, Federal Highway Administration, Washington, D.C., USA, 2016. 
Nordic Concrete Research - Publ. No. NCR 65 - ISSUE 2 / 2021 - Article 6, pp. 107-128

35. Senseney, C.T, Smith P.J \& Snyder M.B: "Precast Concrete Paving Repairs at Vancouver International Airport". Transportation Research Record, 2021.

36. Priddy L.P, Bly P.G, Jackson C.J \& Flintsch G.W: "Full-scale field testing of precast Portland cement concrete panel airfield pavement repairs", International Journal of Pavement Engineering, Vol. 15, No. 9, 2014, pp. 840-853.

37. Airbus: A380 :https://www.airbus.com/aircraft/passenger-aircraft/a380/innovation.html.

38. Aircraft C-17: https://www.theaviationzone.com/factsheets/c17_specs.asp. 